\title{
SOEP
}

SOEPpapers

on Multidisciplinary Panel Data Research
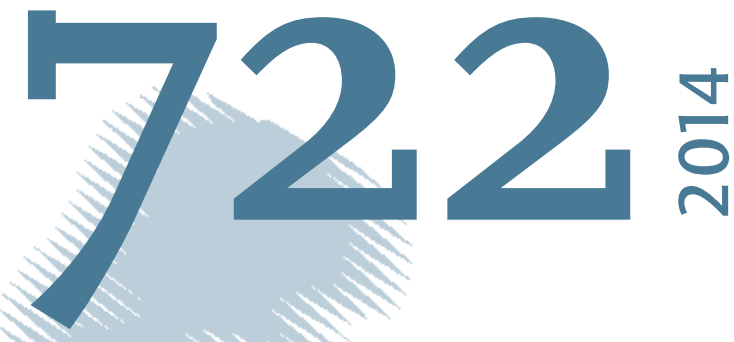

\section{Maternity Leave and its Consequences for Subsequent Careers in Germany}




\section{SOEPpapers on Multidisciplinary Panel Data Research}

at DIW Berlin

This series presents research findings based either directly on data from the German SocioEconomic Panel Study (SOEP) or using SOEP data as part of an internationally comparable data set (e.g. CNEF, ECHP, LIS, LWS, CHER/PACO). SOEP is a truly multidisciplinary household panel study covering a wide range of social and behavioral sciences: economics, sociology, psychology, survey methodology, econometrics and applied statistics, educational science, political science, public health, behavioral genetics, demography, geography, and sport science.

The decision to publish a submission in SOEPpapers is made by a board of editors chosen by the DIW Berlin to represent the wide range of disciplines covered by SOEP. There is no external referee process and papers are either accepted or rejected without revision. Papers appear in this series as works in progress and may also appear elsewhere. They often represent preliminary studies and are circulated to encourage discussion. Citation of such a paper should account for its provisional character. A revised version may be requested from the author directly.

Any opinions expressed in this series are those of the author(s) and not those of DIW Berlin. Research disseminated by DIW Berlin may include views on public policy issues, but the institute itself takes no institutional policy positions.

The SOEPpapers are available at

http://www.diw.de/soeppapers

\section{Editors:}

Jürgen Schupp (Sociology)

Gert G. Wagner (Social Sciences, Vice Dean DIW Graduate Center)

Conchita D'Ambrosio (Public Economics)

Denis Gerstorf (Psychology, DIW Research Director)

Elke Holst (Gender Studies, DIW Research Director)

Frauke Kreuter (Survey Methodology, DIW Research Professor)

Martin Kroh (Political Science and Survey Methodology)

Frieder R. Lang (Psychology, DIW Research Professor)

Henning Lohmann (Sociology, DIW Research Professor)

Jörg-Peter Schräpler (Survey Methodology, DIW Research Professor)

Thomas Siedler (Empirical Economics)

C. Katharina Spieß (Empirical Economics and Educational Science)

ISSN: 1864-6689 (online)

German Socio-Economic Panel Study (SOEP)

DIW Berlin

Mohrenstrasse 58

10117 Berlin, Germany

Contact: Uta Rahmann | soeppapers@diw.de 


\title{
Maternity Leave and its Consequences for Subsequent Careers in Germany
}

\author{
Nele E. Franz* \\ Carinthian University of Applied Sciences \\ Europastraße 4 \\ 9500 Villach \\ Austria \\ mail@nelefranz.de
}

December 18, 2014

\begin{abstract}
This paper analyzes the wage development of mothers interrupting their careers, in comparison to the wages of men who do not face a parental interruption. We estimate OLS regression models for different subcategories defined by age and point in time. We use data from the German Socioeconomic Panel from 1984 to 2011, to show that wages and the financial penalty for maternity differ according to the duration of interruption. We find a lower wage penalty in the short run for women interrupting their careers who are legally protected, but merely delayed penalties for the same group in the long run.
\end{abstract}

JEL classification : C21; J13; J24; J31

Keywords : Human capital; parental leave; wages; OLS

DIW-Keywords : Family and networks, gender, labour, income and poverty

*Phone +43-5-90500-1223. Fax +43-5-90500-1210. 


\section{Introduction}

Gender-specific wage differences are to a large extent explained by careerinterruptions caused by giving birth and caring for children. Because, in most western countries, mothers still take by far the main responsibility for their children, this seems to explain wage differences, quite apart from wage discrimination between the sexes. In this paper, the consequences of maternity leave of different durations is analyzed in the short, intermediate and long runs. It is shown how much wage loss a mother has to bear, through losing one or more years of employment, in comparison to the generally continous careers of men. The main issue is how the length of a job interruption affects the wage penalty and wether it makes sense to get back into full employment early. In Germany, a hotly debated legal right to day-care facilities for 1-3 year old children came into effect on August 1st, 2013. The debate about increasing the supply of child care centers for children between one and three years is strongly associated with the opportunities and penalties in the labor market after an interruption. Since 1986, mothers in Germany have received job protection for a certain period after giving birth, extendet stepwise until 2007. Starting with 10 months of legally regulated maternity leave $^{1}$ in $1986^{2}$, mothers can now interrupt their careers for up to three job protected years. Such maternity leave may influence decisions on the length of an interruption, and definitely have an impact on subsequent payments. The previous literature mostly ignores the legal circumstances of career interruptions. Furthermore, pathbreaking approaches of Mincer and Polachek (1974) and Mincer and Ofek (1982) deal with premissions and data under completely different conditions. This present approach includes those concepts about work profiles of mothers interrupting their careers due to children with respect to the more recent circumstances, using data from the German socio-economic panel (SOEP) covering the period 1984-2011. This period just covers the main years since job protection for young mothers were introduced. The main consern of our analysis is how the duration of maternity leave affects subsequent wage consequences and wether the job protection that has been implemented and expanded continously in Germany plays a role in the formation of wage penalties. Of particular interest is wether job

\footnotetext{
${ }^{1}$ Note that " 'Maternity Leave"' in this article is used as a generic term for any employment interruption connected with childbearing.

${ }^{2}$ Note that an earlier introduction of a job protected six months cannot be considered here, since no data is available for this period.
} 
protection really prevents or merely delays wage penalties for mothers leaving employment due to childcare responsibilities.

The paper is organized as follows. We next provide an overview of the related literature and some empirical findings for Germany. In Section 3, the theoretical background to this approach is described, namely the concept from Mincer and Ofek (1982), which is adapted to the German case. In Section 4, we present our methodology and the variables used. After explaining our summary statistics in Section 5, we present our estimation results in Section 6. Section 7 concludes.

\section{Previous Literature}

The gender gap in general and especially the costs of employment interruptions due to maternity leaveis already the focus of a substantial body of literature before. The majority of empirical studies uses the National Longitudinal Survey of Labor Market Experience of Young Woman, a Panel Survey for the USA. For Germany, several studies use mostly either employer-employee survey data provided by the Institute for Employment Research (IAB), or data from the Socio-Economic Panel (SOEP).

The main literature about the costs and consequences of career interruptions is based on the human capital approach of Gary S. Becker (1964, 1985) and the wage equations of Jacob Mincer (1974). Becker explains differences in men's and women's wages with respect to gender-specific investments in human capital. Following his argumentation, women do not invest in human capital as much as men, because women anticipate career interruptions and family responsibilities (Becker 1985). Mincer and Polachek published the first concrete analysis of maternity leave and womens' earnings in the context of their households (Mincer/Polachek 1974). In their approach, wage profiles after schooling are segmented into (up to eight) periods of participation and non-participation, which facilitates a differentiated analysis of investment and the depreciation of human capital. The seminal paper of Mincer and Polachek (1974) has been the basis of many further approaches to measuring the effect of career interruptions. Their paper focuses on investments in human capital after schooling and differentiates between several household types connected with marriage and children. Mincer and Ofek followed this paper with a first longitudinal analysis of panel data, in which the long- and short-term consequences of career interruptions due to moth- 
erhood for employed married white women in the USA are discussed. They simplify the former approach, outlining a work-life profile including only one interruption. The implementation of a restoration effect catching up a shortrun wage penalty is the essence of the matter. Mincer and Ofek conclude that a wage penalty does result from career interruptions for married women and that the short-term effects exceed those in the long run. The aim of the present paper is to cobstruct a wage profile for women over their lifetime, thereby rethinking the prevalence of a restoration effect. However, the definitions of long- and short-term effects being either just dropped into the market or resuming work at least one year ago leave room for interpretation. (Mincer/Ofek 1982)

Waldfogel (1997) presents a study for women in the USA, in which not only the lack of labor market experience is regarded as an explanation of the family gap between women with and without children. Instead, Waldfogel explains a 'child penalty' in wages by differentiating between work experience in full- and part-time jobs. Furthermore, Waldfogel takes possible heterogeneity between mothers and childless women into account. In this study, a wage penalty of 4 percent for one child and 12 percent for two or more children remains, even after controlling for time-invariant personal characteristics (with a individual fixed-effects model), part time experience and current part time employment (Waldfogel 1997).

Another study (Waldfogel 1998) presents a comparison between firstdifference- and fixed-effects-estimations for family gaps in the USA and Great Britain. A decomposition of subsequent wages shows that 41 percent (for the USA) and 48 percent (for GB) of the total wage gap between middle-aged men and women can be explained by differences in the financial returns of family and parental status between the sexes. In addition to these results, Waldfogel analyzes the use of maternity leave protection and finds that in Great Britain and the USA, the wages of women who benefit from maternity leave protection gain much more than mothers who are not legally protected. Maternity leave protection is more advantageous, the earlier women start working after giving birth (Waldfogel 1998).

Budig and England (2001) consider the possible reasons for a wage penalty for motherhood, using and extending Waldfogel's (1997) study. Budig and England point out five possible reasons for a family gap: 
Experience: interrupted (full-time)employment and consequent lack of work experience,

Choice: accepting lower wages in advance through jobs that are better to combine with family responsibilities,

Productivity: productivity losses at work when having responsibilities for children at home,

Discrimination: employer discrimination and,

Heterogeneity: unobserved heterogeneity, e.g. the correlation between motherhood and lower wages may not entail causality.

The article focuses on different job characteristics, different industries and influences of marriage and childbearing on wages. However, it does not answer the question about the different effects of parental leave in the short and the long run.

Furthermore, Anderson, Binder and Krause (2002) find strong evidence of an educational correlation with the size of the family gap. In their cross sectional and fixed-effects study, educational level (no diploma/high school graduate/college graduate) is a key influencing variable for predicting the magnitude of the wage penalty for one child and with a greater intensity for two or more children. While low-skilled mothers do not suffer any wage penalty for one or more children, for highly skilled mothers, a wage penalty of four percent for one child and 15 percent for two or more children is identified (Anderson/Binder/Krause 2003).

For Germany, Kunze (2002) finds different wage penalties for career interruptions caused by unemployment, non-work and parental leave. Parental leave, especially for women, incurs the highest short- and long-run wage penalty, with up to 18 percent wage losses compared to pre-birth wages. Kunze uses data from the IAB employment sample (IABS) from 1975 to 1997 and applies it to an expanded model, relying on Mincer and Polachek (1974).

Beblo and Wolf (2003) find different consequences of work interruptions for men and women and differences in the consequences of unemployment periods, time outs and parental leaves. They find evidence of a higher wage penalty for maternity leave in comparison to paternal leave or interruptions for any other reason. However, their analysis is limited to full-time employed 
40 year old men and women in West Germany (Beblo/Wolf 2003). A more recent study using data from the German Socioeconomic Panel (SOEP) identifies different short- and long-run effects of maternity leave on wages (Goerlich/De Grip 2009). However, the focus of that study is the dependancy of skill levels and the depreciation of human capital, rather than the impact of the length of an interruption and the duration of wage restoration after a maternity break. The main hypothesis is based on occupational segregation between men and women, as a result of different wage penalties in female-dominated in contrast to male-dominated jobs. Therefore, the differentiation between short- and long-run effects of career interruption remains rather vague - the authors simply differ between less and more than five years since reentry into the labor force. The results show that there is a difference between low- and high-skilled occupation, as well as significant catch-up or restoration effects of employment on wages. A clear (long-run) difference in the restoration of wages in male or female dominated sectors is not found (Goerlich/De Grip 2009).

Most of the recent studies for Germany use data from the German Socioeconomic Panel (SOEP) and the Institute for Employment Research (IAB) to investigate decisions on the length of maternity leave and the direct wage effects of maternity leave. Ejrnoes and Kunze (2013) find a direct wage penalty of 3-5.7 percent per year of maternity leave. Kuhlenkasper and Kauermann (2009) find that the duration of maternity leave depends, besides educational level and prebirth income, also on the legal framework in Germany.

In this analysis, we take those findings on the importance of skills, family background, duration of reemployment and occupational cases into consideration. To the best of our knowledge, this is the first investigation of womens' wage penalties, in comparison to equivalent male wages at different points in time. Our analysis provides not only an intrapersonal comparison of wages before and after an interruption, but shows the (in our opinion) the real wage penalty by comparing female wages to those of male counterparts of the same age and not facing maternity leave. In addition, throughout our estimations in the short, intermediate and long run, we take potential delayed wage penalties into account. As a result, we can compare wage development for mothers in comparison to men. We took men's wages as a reference group, since we assume male wages constitute real market wages. ${ }^{3}$ Furthermore, we focus on the existence of a restoration effect defined by Mincer and Ofek

\footnotetext{
${ }^{3}$ For a discusssion about reference wages see Oaxaca (1973)
} 
(1982). Firstly, we analyze wether there is a restoration of (possibly) reduced wages after an interruption and secondly, we explore wether wage growth in that critical period directly after an interruption is faster for mothers than for men, since there, in our opinion are the key ctriteria for analyzing the wage effects of maternity leave.

\section{Wage penalties for interrupted work ca- reers}

Mincer and Ofek (1982) decompose female life-cycle employment into four periods:

Period 1: The pre-birth period starts with the completion of education, i.e. an academic degree. In comparison to male career paths, the pre-birth years of female wage development may be less steep, but essentially linear and - due to human capital gains - increasing. If an interruption is anticipated, effort and investments in human capital may be lower, so that a flatter wage growth curve may be reasonable.

Period 2: While men follow this linearly increasing wage path until retirement, (many) women interrupt their career when giving birth. In that second period, wages are expected to be zero. For simplicity, women are assumed to interrupt their career only once.

Period 3: Starting the third period, when mothers return to work, Mincer and Ofek (1982) assume that mothers will reenter into employment at a lower wage level than before. During their interruption, women not only fail to accumulate more human capital, but also face a depreciation of their previously accumulated human capital. The longer the interruption, the more human capital is depreciated and the lower the reentry wage. The "restoration period" (Mincer/Ofek 1982, p. 5) is characterized by catching up with pre-birth wages. Mincer and Ofek identify greater wage growth during the first five years after an interruption period, which they associate with the accumulation of job tenure.

Period 4: The fourth period describes a post-restoration interval with wages growing as fast as men's or slower, if another interruption is expected 
later on. Graph (a) in Figure 1 depicts these four periods of employment introduced by Mincer and Ofek (1982).

(a)

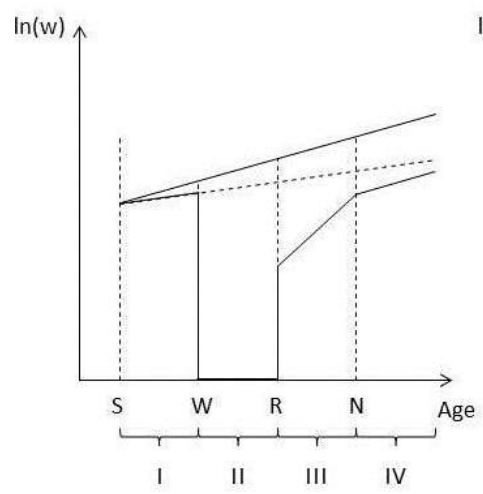

(b)

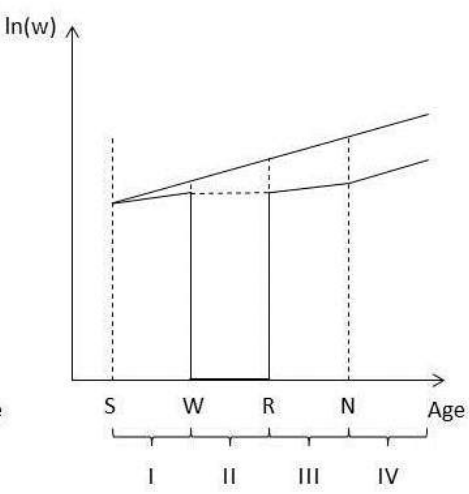

Figure 1: Stylized wage profiles over lifetime

Note: Graph (a) Mincer and Ofek concept (1982); Graph (b) possible adjustments; (S) defines starting point of employment after completing education, (W) pictures withdrawal of employment, (R) marks reentry into employment and (N) specifies a "normalization" of wage growth

Of particular importance for this approach is the finding that mothers earn less than before when reentering into employment. Based only on depreciating wages during a break, a subsequent 'restoration of wages' afterwards can be derived. However, in many countries social regulations associated with parental leave were expanded consiberably since the early 1980's. In Germany, since 1979, mothers have had a job-protected maternity leave of up to six months. After 1985, maternity leave legislation was extended from 8 months in 1986 to 34 months in 1993. Note that these are job protection terms, and not of paid career breaks (see Ejrnoes and Kunze (2013) for a brief overview). Since 1993, mothers (or fathers) have a right to one-year of compensation for interruptions, which they may split over 24 months. In 2007, compensations was increased to 67 percent of former income (but not more than 1800 Euros) and parental leave is paid for 14 months, if both 
parents share time off employment. However, a wage decline is prohibited for employment interruptions up to three years.

From this, it follows that a restoration effect will not take place either. Broken down into hourly wages, women can even earn slightly more after an interruption than before. Individual differences between women's hourly wages when reentering after an interruption caused by child-care and wages when leaving employment are, in this data set, positive with an average difference of 0.457 Euros/hour (for a closer look at average wages see also Table 2). This means that the entire discussion about a restoration effect catching up previously declined wages has to be reconsidered. Wage profiles are likely to follow a different pattern than those predicted by Mincer and Ofek (1982).

For more recent data, we assume that instead of a larger growth in postinterruption wages, those of mothers grow slower than before their break. Following Mincer/Ofek and others, the human capital of mothers declines during their break. Therefore, in relation to their human capital, mothers are overpaid when returning to work, if job protection prohibits lower reentry wages. Additionally, the majority of mothers returning to work then work only part-time. Working part-time is associated with less human capital accumulation and therefore lower wage advances. In the first years after an employment interruption, the wages of mothers grow only slowly. Consequently, the wage-gap between men and mothers increases. The cost of non-participation is lower in the short run, but increases due to slower growth-rates.

Although women may restore their former depreciated human capital, employers will compensate for overpayment by suspending subsequent wage increases. In a following period - when human capital and wages have leveled off once again - wage development will continue as before child-bearing. At this point in time, the differences between men and mothers no longer increase. In the long run, wage profiles will approach those of men (but at a lower level) when human capital and wages again correspond to each other. Graph (b) in Figure 1 depicts our idea about the development of wage profiles, which is tested here. Obviously, the main difference from Mincer/Ofek (1982) is the period after work career interruption.

So far, an interruption has been considerd in the literature to entail an undifferentiated time period. However, since financial support and job protection are limited, there may be differences in reentry wages, and therefore in the further development of wages, depending on the length of interruption. 
The Consequences of breaks may not increase linearly with the length of an interruption, because not only the depreciation of human capital, but also job protection is relevant here. Our approach categorizes interruption spells depending on their legal framework and the age of the children. Maternity leave is partitioned into four interruption time categories $j \in\{1,2,3,4\}$ :

First A short maternity leave of up to one year. In Germany, a parental allowance since 1979 is paid for the first 12 months after giving birth. Since 2007, parents can receive a parental allowance for 14 months for single parents, or if the parental leave is shared between mother and father. However, since less than 2.5 percent of all mothers and no statistically relevant share of fathers receive parental allowance for more than 12 months, the relevant period for mothers still is the first year after birth (Federal Statistical Office 2013a).

Second The protected period for interrupting employment for parenting without the employers' agreement ends with the third birthday of a child.

Third This category is defined as staying at home until children are old enough to attend kindergarten/nursery schools, which in Germany starts at the age of three and ends on entering school at the age of six. This is the first categorical period in which parents are no longer protected, so that a significant rise in wage differentials is expected, in contrast to the first two categories. Mothers belonging to this category spend between three and six years at home.

Fourth This category comprises upon mothers who (at the earliest) start working when their children attend elementary school. The last category includes all working mothers who do not work for 6 years or longer after giving birth to their first child. Referring to Mincer and Polachek (1974), this would be the third stage of sustainable reemployment on which Mincer and Polachek focused (Mincer/Polachek 1974, p. 83). Clearly, periods of labor market participation have shifted over time.

Based on these four types of interruption, the influence of maternity leave duration will be explored through different estimations for each type. Simply stated, our hypothesis is that there is an increase in long-run wage penalties for each longer type of interruption. In the short run, the main difference 
is expected between the second and third types, because they are located exactly on the border of legal job protection.

\section{Empirical Approach}

The aim of this analysis is to identify wage penalties for work interruptions due to maternity and explicitly to reveal differences in these penalties depending on the length of interruption. To keep the analysis simple and to avoid interaction effects, only women with one birth-related career interruption are considered. The number of children is of inferior interest here, because we focus on the consequences of a single interruption. As shown in Figure 1, the wage profiles of men and women without children are assumed to proceed linearly during their lifetime, even though women's profiles may be flatter. Men's wage profiles are used only as a reference, since a "normal" wage profile without distortions due to mootherhood or discrimination is most likely there. ${ }^{4}$ Nevertheless, the wages of women without children are taken into accountadditionally in separate estimations.

\subsection{Methodology}

The structure of our analysis is deliberately kept simple, although the advantages from the panel structure of the data used are fully exploited. Through ordinary least squares regressions at four different points in time, we are able to draw a picture of the consequences for women of dropping out of employment due to child-care. Employment interruption is partitioned into four break-time categories $j \in\{1,2,3,4\}$, as already described in Section 3. For each estimation, a different sub-sample is developed, consisting of (future) mothers of each type of $j$.

Additionally, the sub-sample includes all men in the same age group as the observed mothers. The different age groups are defined by the 25 th and the 75 th percentiles of the corresponding motherhood group. Table 4 in the appendix describes the relevant sub-samples. We compare men and women of the same age, matching them in different subsamples. For each type of interruption, estimations of wages in four points of time $k \in\{1,2,3,4\}$ are

\footnotetext{
${ }^{4}$ Of course, the reverse assumption also could be made and lower female wages could be used as the reference, but that would not change the results substantially. For a detailed discussion on this, see Oaxaca (1973).
} 
conducted, namely (1) year of withdrawal, (2) year of reentry into the labor market, (3) 5 years after reentering and (4) 10 years after reentering the labor market. For example, the first subsample refers to women immediately before giving birth, who will exit employment for one year or less $(j=1)$. These women are between 25 (25th percentile) and 30 (75th percentile) years old. The corresponding group of men are all aged between 25 and 30 . The last measured wage before maternity leave, and the wages of men between 2530 years old together form the dependent variable. The same procedure is done for women reentering employment and so on. All in all, 16 subsamples constitute the basis of our estimations. Withdrawal and reentry wages are estimated in order to explore the short-run effects of maternity leave. Given that Mincer and Ofek demonstrate a restoration effect within the first five years after an interruption, the third point of time at which wages are estimated is five years after reentering employment, since there should be either a restoration effect or a (assumed here) delayed wage penalty. Finally, ten years after an interruption, wage development should have normalized and the wage penalty of motherhood will hypothetically not increase between the fifth and tenth year after an interruption. Measuring the wage effects of maternity leave in comparison to male wages at the same age, enables us to observe not only absolute wage losses and gains for an individual, but also to compare them to a "normal" wage profile not affected by interruptions. We assume that maternity leave has two effects. First, a real wage loss comared to earlier wages. Second, an indirect wage loss through no or slower wage growth during an interruption and during the post-interruption period. Both effects can be estimated through our approach of comparing cross-sectional estimations.

The underlying wage equation follows a standard Mincer wage equation. For each type $j$ and date $k$ the following is estimated:

$$
\ln \left(w_{i}\right)=\beta_{0}+\beta_{1} \text { break }_{\mathrm{i}}+\beta_{2} \mathrm{edu}_{\mathrm{i}}+\beta_{3} \exp _{\mathbf{i}}+\beta_{4} \mathbf{x}_{\mathbf{i}}+\epsilon_{\mathrm{i}}
$$

where $i$ indexes individuals, $\mathrm{w}_{i}$ denotes the individual wage of a mother immediately before the first birth as well as 0,5 or 10 years after reentering the job market, or the individual wage of a man in the same sub-sample. Note that there is only one observation for mothers in each subsample, but up to seven observations for each man in the age group belonging to specific events. A woman reentering the labor market after a one year interruption is aged between 27 (25th percentile) and 32 (75th percentile). Accordingly, the 
wages of each man between the ages of 27 and 32 belong to that subsample. To account for this, we used robust standard errors. Since the wage equation is estimated at different points in time, the estimation comprises to a cross sectional analysis.

The explanatory variable of interest is the employment interruption caused by the first birth, namely break $_{i}$, defined as a dummy variable representing the women in the sample. Edu $\mathbf{u}_{i}$ describes education, the vector $\mathbf{e x p}_{\mathbf{i}}$ includes experience variables. The vector $\mathbf{x}_{\mathbf{i}}$ captures the remaining individual controls. With this simple OLS equation, we are able to differentiate between wage penalties in the long and in the short run, concentrating on the different length categories of interruption.

\subsection{Data and Variables}

This analysis is based on data from the Socio- Economic Panel (SOEP), a representative survey of private households in Germany, yielding data from 1984 to 2011 (Wagner/Frick/Schupp 2007, SOEP 2011). The advantage of this data set is its size in terms of respondents per year, as well as its length of 28 waves from 1984 to 2011. These data faciliate an analysis of long-run consequences of a career break related to giving birth in Germany, and with a satisfactory number of observations. Since continuous and complete data from 1984 to 2011 for each person are not statistically necessary, and in order to maximize the number of observations, the panel data used here are unbalanced. The sample is limited to individuals between the ages of 20 and 67. No observed individuals should be older than 45 when the documentation started in 1984, since the employment of mothers and the duration of their interruptions cannot be observed retrospectively. For the same reason, women with children born before 1983 are dropped from the sample. Our data set consists of 33,485 individuals, of whom 49 percent are women. 55 percent of the men and 45 percent of the women have children living in the same household and are born after 1982 .

The independent variable in this study is the hourly wage of mothers and men (mothers and women without children) belonging to the different subsamples defined by $j$ and the corresponding age group (cf. 4). Altogether there are 16 different subsamples, each representing interruption types $j \in$ $\{1,2,3,4\}$ and $k \in\{1,2,3,4\}$ measurement events.

Following the standard methodology, all wage-related variables in the regression estimations are logarithms. Wages are defined here as generated 
hourly gross labor income, calculated from the generated gross monthly wages of employed individuals and the number of hours worked. Self-employed persons are not included. Calculating hourly wages is appropriate, because such a wage is not influenced by reduced working hours, which is a popular form of employment for mothers. In the socioeconomic panel, two different specifications of weekly working hours are offered. First, there are agreed weekly working hours, which refer to contractually specified hours. Second, actual working hours per week are based on a question about how many hours respondents work per week on average. We prefer actual working hours, because SOEP sided adjustment is the limitation of weekly working hours to a maximum of 80 hours. Here, actual working hours, are replaced by agreed weekly hours if actual working hours are specified as lower than 30 hours, but the employment status is given as full time. The same procedure is applied to part-time work and implausible actual working hours. If actual and agreed weekly hours are implausible, actual working hours are replaced by the average values for part-time and full-time employment. ${ }^{5}$ Monthly wages are divided by actual working hours per week (times four), so that (unpaid) overtime is included to generate a realistic measure of employee payment. Gross wages are used here because of the German tax system, especially the parental split, which could otherwise bias the results (Ziefle 2004). All wages are deflated with the Consumer Price Index, which is published annualy by the federal statistical office (2013b) and presented in 2010 prices.

The most important independent variable is the binary variable representing maternity leave. Since the samples are split, a dummy representing all mothers per sample describes the wage effects of maternity leave in comparison to male wages. A further independent variable is the human capital indicator containing a generated variable which converts school and job-related education into general years of education ${ }^{6}$. As one of the most important human capital variables in this analysis, experience is included as missed experience, defined as potential experience (age minus 6, minus years of education) minus actual work experience.

The control variables are marriage status, (direct) migration background and residence in East Germany (former GDR). All these variables are defined binary. In East Germany, wage differences between mothers should be

\footnotetext{
${ }^{5}$ Implausible and missing values are replaced by 22 hours for part-time employment and 40 hours for full-time employment. Agreed/Actual weekly working hours for full-time employment are 39/41, for part-time employment 20/24 hours, respectively.

${ }^{6}$ For detailed information about the underlying codification see (Anger et al. 2011)
} 
lower, because of the historically stronger labor market orientation of mothers. Especially marriage is accorded a high level of attention in Mincer and Ofek (1982) and Mincer and Polachek (1974). We no longer attach such high importance to marriage status and do not differentiate between couples simply living together and those living together and married. Both categories are integrated into the binary variable marriage. Tests estimated with stricter definitions of marriage did not change the regression results significantly. Migration background applies if a person was born outside Germany. The remaining household income, measured in Euros earned in addition to individual income per year, may be relevant for the decision on when and at what wage mothers return to work.

Information about the occupational environment is additionally included. The size of the company is a discrete variable split into four levels: (1) less than 20 employees, (2) between 20 and 199 employees, (3) 200 to 1999 and (4) 2000 and more employees. Company size may influence the length of an interruption as well as the subsequent growth of wages. A larger company is assumed to be able to compensate maternity leaves better than small ones. Moreover, large companies may provide a better infrastructure such as daycare facilities or schooling for reentering mothers. The size of a company is assumed to have a positive effect on wages for mothers (Busch/Holst 2013).

Another job-related variable is the sector in which an individual works. Traditionally, the service sector has a higher proportion of women than manufacturing. The third observed sector is trade, transport, accommodation and food services, abbreviated as trade. Being employed in the civil service is documented additionally as a dummy variable. The profession of an employee may also be dominated by males or females. Like Busch/Holst (2013), we describe sexual segregation of professions as female-dominated if the share of women in the particular occupation is at least 70 percent. Professions in which 30 percent or fewer women work are defined as male dominated. The remaining professions are called intermediate and used as the reference category. The final job-related variable is the identification of a job as a leading position. This binary variable is taken out of the occupational position information specified in the data. Characteristics described as "managerial", "highly qualified professional" and "executive civil servant" are combined to form the binary variable leadership (Busch/Holst 2013). 


\section{Descriptive Analysis}

Our analysis of the consequences of a child-related career interruption for mothers starts by observing of the general wage impact of children on women and men. In Table 1, the average gross monthly and hourly wages reveal a clear difference between the wages of men and women, and an even more distinct difference between the wages of fathers and mothers; on average, fathers earn twice mothers' monthly wages. Obviously, this difference is influenced by the 24 percent of all mothers working part time (defined as less than 35 working hours a week), while for men part time work does not play a notable role. The hourly wages convey a more accurate impression of the wage differences between men and women and fathers and mothers. It becomes apparent that there is a difference between the wages of men and women and that this difference increases with the existence of children. Since the men in our sample are older, seniority and labor force experience might be partly responsible for the measured wage gap, but education may well not, since the observed years of schooling and training are similar.

Figure 2 shows the stylized lifetime development of hourly wages lifetime for men, women without children and mothers aged 20 to 60. Men clearly earn more than women and women without children earn more than mothers. While in their early 20s, women without children and men have similar, steeply rising wage rates, the growth in wages of older women and especially of mothers is flatter. Up to the age of about 40, men's wages increase faster than those of women. Men's wage growth declines with advancing age, while the wages of women without children seem to grow more constantly over time. The lowest wage growth is faced by mothers in their 30s and 40s. Afterwards, possibly when the children's age allows more intense labor force participation, wages grow faster than those of women without children and even than those of men. The wage gap between men and mothers declines while the gap between women without children and mothers disappears completely. Note that because of a declining number of observations with rising ages, jumps in average earings beyond the age of 50 may not be sufficiently reliable to interpret meaningfully. Altogether, the inspection of average hourly wages over a lifetime supports the hypothesis of a catch-up effect for mothers.

Splitting up the descriptive statistics about mothers into categories of the length of their career interruptions reveals considerable differences in personal and human capital characteristics. The longer the time out of the 


\begin{tabular}{l|cccc}
\hline & \multicolumn{2}{|c}{ without children } & \multicolumn{2}{c}{ with children } \\
& male & female & male & female \\
\hline Gross monthly wage & 2827.59 & 2173.55 & 3514.39 & 1717.26 \\
& $(2107.432)$ & $(1470.59)$ & $(2672.96)$ & $(1377.36)$ \\
Gross hourly wage & 16.51 & 13.97 & 19.70 & 14.39 \\
& $(11.53)$ & $(8.27)$ & $(13.12)$ & $(9.34)$ \\
Actual work experience & 16.00 & 9.59 & 20.07 & 10.91 \\
(years) & $(13.15)$ & $(10.55)$ & $(11.16)$ & $(7.46)$ \\
Missed experience & 5.05 & 4.04 & 4.55 & 7.56 \\
Part-time/Full-time & $(4.40)$ & $(4.90)$ & $(3.86)$ & $(5.43)$ \\
& 0.12 & 0.22 & 0.03 & 0.30 \\
Age & $(0.28)$ & $(0.35)$ & $(0.13)$ & $(0.31)$ \\
Education (years) & 37.29 & 34.09 & 40.86 & 36.13 \\
& $(12.79)$ & $(11.68)$ & $(11.52)$ & $(8.00)$ \\
Actual working hours & 12.12 & 12.38 & 12.28 & 12.18 \\
per week & $(2.61)$ & $(2.62)$ & $(2.78)$ & $(2.55)$ \\
\hline
\end{tabular}

Table 1: Descriptive statistics for males and females with and without children; standard deviations in parentheses 


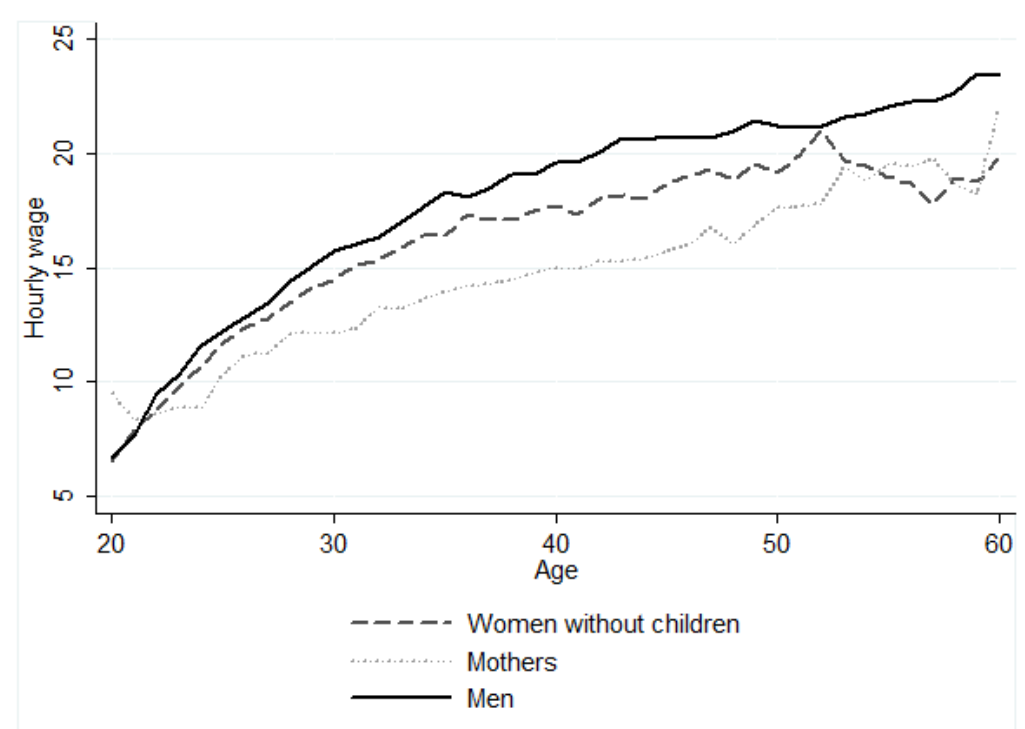

Figure 2: Lifetime stylized wage profiles

labor force, the younger (when giving birth), less educated and experienced the mothers tend to be. In comparison to women without children, mothers earn less per month and per hour. The only exception are mothers spending less than or exactly one year in maternity leave,for whom advanced age and education may play a role. It is conspicuous that mothers living in the former GDR spend less time out of work on average, and interruptions exceeding six years are rare. As expected, the share of parttime experience is much higher for all women than for men, while there is only a small difference between women without children and mothers facing the four different categories of interruption. For a detailed descriptive overview, see Table 5.

The mean duration of a child-related career interruption in this dataset is two years, starting at an average age of 27 years and with full-time experience of five years. In Table 2, the wages of a man and a woman with no career interruption (Columns 1 and 2) are compared to mothers facing maternity leaves of different durations referring to the categories described above. The first column represents an average person with 1.3 to 8 years of full-time labor experience, facing no interruption and gaining two more years of full-time experience before measuring "reentry hourly wage".

The average hourly wages on withdrawal show that women with higher 


\begin{tabular}{l|cccccc}
\hline Category of Interruption & $\begin{array}{c}\text { None } \\
\text { male }\end{array}$ & $\begin{array}{c}\text { None } \\
\text { female }\end{array}$ & $\begin{array}{c}\text { First } \\
0-1 \text { years }\end{array}$ & $\begin{array}{c}\text { Second } \\
1-3 \text { years }\end{array}$ & $\begin{array}{c}\text { Third } \\
\text { 3-6 years }\end{array}$ & $\begin{array}{c}\text { Fourth } \\
6<\text { years }\end{array}$ \\
\hline Withdrawal age (median) & 27 & 27 & 28 & 27 & 27 & 26 \\
\hline Hourly wages on withdrawal & 13.12 & 12.12 & 14.70 & 13.96 & 13.87 & 12.48 \\
& $(5.38)$ & $(4.99)$ & $(6.00)$ & $(5.29)$ & $(5.73)$ & $(5.33)$ \\
Reentry hourly wage & 15.71 & 13.50 & 15.25 & 13.71 & 13.87 & 11.81 \\
& $(10.09)$ & $(12.94)$ & $(7.45)$ & $(7.30)$ & $(7.67)$ & $(7.86)$ \\
Hourly wage & 17.63 & 14.19 & 17.08 & 13.37 & 12.22 & 11.20 \\
5 years after reentry & $(7.91)$ & $(7.11)$ & $(9.87)$ & $(6.17)$ & $(5.00)$ & $(4.86)$ \\
Hourly wage & 19.09 & 15.18 & 16.49 & 14.75 & 13.07 & 13.15 \\
10 years after reentry & $(8.87)$ & $(7.85)$ & $(9.12)$ & $(6.52)$ & $(5.40)$ & $(8.10)$ \\
\hline
\end{tabular}

Table 2: Mean withdrawal and reentry wages by length of interruption period; standard deviations in parentheses

earnings before giving birth will on average choose a shorter maternity leave. Leave of one year or less for maternity does not seem to have a large impact on wages or wage growth in the short and intermediate run. The level of income in this group is higher than for any other female group and even starts at a higher level than men (withdrawal wages). Only in the growth of average wages can a penalty for interrupting work careers be observed for women with a short maternity leave of one year or less. In the long run, after 10 years of employment after a child-related interruption, a decline in average wages is evident. This finding might indicate a delayed wage penalty as described in our hypotheses. For longer interruptions, the highest wage penalty for interruptions can be seen five years after an interruption. While for breaks between one and six years, there is no or only a slight wage decline directly after an interruption, a break exceeding six years leads to considerably lower wages immediately after reentering the labor market. In comparison to men, a catch-up effect cannot be observed for any mother facing a career interruption. In comparison to women without children, the average results are not clear; while for the first and third category, wage growth for mothers is slower than for women without children at any time, for categories two and four wages grow faster between the fifth and tenth year of employment after an interruption, than the wages of women without children.

Alltogether, we see constantly increasing wages for men and women not facing maternity leave, while mothers with all types of interruptions have 
to accept declining wages at least once. However, the time lag between reentering the labor force and wage declines differs.

\section{Results}

Our descriptive results support to the assumption of delayed or even nonexistant restoration effects for different groups of interruption. Table 3 presents the key results of our estimations, summarizing the influence of maternity leave on wages for all different types of interruption, in comparison to men. For a detailed overview of our estimations, including the results for each variable in each estimation, see also Tables A.6 to table A.10 in the appendix. As already evident from the descriptive analysis, maternity is associated with a significant wage surplus before exiting employment, but only if interruptions are not too long.

For mothers leaving employment for one year or less, a wage difference compared to men even after an interruption is still significantly positive. Five years after an interruption (or later), however, there is no siginficant difference between the wages of men and mothers who have had a one-year break. Later on, the difference remains insignificant, and even becomes negative. Interpreting these findings as much as possible in the context of a restoration effect, we find no catch-up of wages, either in the short or in the long run. Job protection during early motherhood may prevent mothers from losing their jobs, but may not prevent a wage penalty. Since estimates for lags in wages five and ten years after reemployment are not significant, a significant difference between men's and mothers' wages cannot be measured.

For mothers interrupting their careers for more than one and up to three years, a wage surplus before entering maternity leave completely disappeares when reentering the workforce. Note that during this period, women are still job-protected, so that the wage growth of men will be the main reason for the catching up of women's wages during a period of 1-3 years. Our descriptive findings in Figure 2 underline these results. Precisely during the period in which most women interrupt their careers for maternity reasons, men achieve the highest wage growth over their lifetime. The advance in the wages of women with career breaks shorter than three years disappear during or after the interruption. Moreover, for women belonging to interruption group two, the wage penalty in comparison to men rises significantly over time. We find a significant delayed wage penalty for mothers after five and 


\begin{tabular}{lcccc}
\hline category of & First & Second & Third & Fourth \\
interruption & 0-1 years & 1-3 years & 3-6 years & 6> years \\
\hline Withdrawal & $0.111^{* * *}$ & $0.159^{* * *}$ & $0.080^{*}$ & 0.030 \\
& $(0.026)$ & $(0.031)$ & $(0.040)$ & $(0.044)$ \\
Reentry & $0.074^{* *}$ & 0.010 & $-0.159^{* * *}$ & $-0.189^{* *}$ \\
& $(0.032)$ & $(0.036)$ & $(0.047)$ & $(0.072)$ \\
5 years after & 0.036 & $-0.093^{*}$ & $-0.191^{* * *}$ & $-0.251^{* * *}$ \\
reentry & $(0.039)$ & $(0.050)$ & $(0.052)$ & $(0.051)$ \\
10 years after & -0.053 & $-0.121^{*}$ & $-0.122^{* *}$ & $-0.234^{* * *}$ \\
reentry & $(0.039)$ & $(0.063)$ & $(0.057)$ & $(0.076)$ \\
\hline
\end{tabular}

Table 3: $\beta$ Coefficients for mothers and men; robust standard-errors in parentheses; $* * * / * * / *$ denotes significance at the $1 \% / 5 \% / 10 \%$ levels

even after ten years subsequent to reentering employment. We do not observe any restoration effect for women taking maternity leave up to three years.

Women interrupting their career for longer than three years (categories three and four) do not have or only have a slight wage surplus in comparison to men of the same age when leaving workforce due to maternity. For these mothers, the direct wage penalty for interrupting their careers (on reentering workforce) is significant and remarkably high. Women leaving employment for three to six years will earn 15.9 less, and those leaving for more than six years will earn 18.9 percent less than their male counterparts of the same age. For those, and only those women, a wage penalty as described by Mincer and Ofek (1982) can be found in our more recent data for Germany and in comparison to men. Here a slight catch-up in wages can be noted after 10 years of employment. However, this marginal restoration of wages still is not sufficient to confirm the applicability of Mincer and Ofek'sresults (1982) in the context of Germany.

This supports our hypothesis that a direct wage penalty prevented by law for short breaks directly after reentering labor force will only delay and not prevent a wage loss caused by reduced wage growth in the long run. We find no evidence of a substantial restoration effect for any of the clustered types of mothers. Since wages in the initial situation for most mothers are significantly higher than those of men, there should have been an even more 
distinct catch-up effect between reentry and later wages.

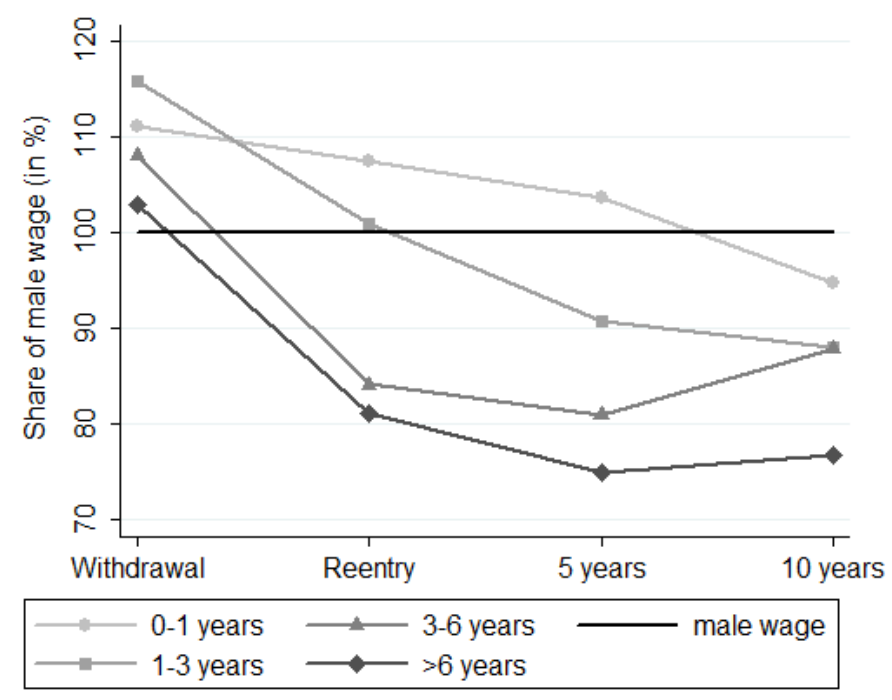

Figure 3: Wage development of mothers in shares of mens' corresponding wages

Note: $\beta$ Coefficients for being a mother for all different subsamples; Note that 100 percent, for each estimated wage difference, is the equivalent wage of men in each age-specific subsample

Figure 3 stylizes the estimated results for wage penalties due to motherhood in relation to men's wages. ${ }^{7}$ For maternity leaves lasting longer than three years, the highest wage penalty can be seen after five years, after which the male-female gap declines slightly. For shorter interruptions, the mothers' wages in comparison with men's wages in the same age category detoriate continously. Taking the wage differences into account when mothers leave employment, the wage penalty for women leaving employment for one to three years is more severe in the long run. Here, a delayed wage penalty may compensate for the job protection during maternity leave and therefore worsens wage developments after an interruption. After ten years, the wage

\footnotetext{
${ }^{7}$ Note that for some estimates, especially for short maternity leaves (0-1 years), the third and fourth estimation is not significant and therefore should not be interpreted as such.
} 
difference between them and their male counterparts is the same for mothers spending 1-3 years or 3-6 years out of the workforce.

Education is one of the most important human capital indicators and as such plays a major role for determining the wage level. For all categories of motherhood, education is most important for wages after reetering employment, while the differences of the influence of education between the categories is small, but rising in accordance with the length of interruption. Before maternity leave, the influence of one more year of education varies between 0.4 percent for mothers in category four, to 1.2 percent in category three. After ten years of employment subsequent to materity leave, this influence rises to 4.0-4.9 percent. The importance of missed experience does not vary much according to duration and category; through all groups and points of time, the results vary around a 1.8 percent wage loss for each additional year missed.

The size of a company has a highly significant and positive influence on wages bur this does not vary over time or between the different groups for which estimations are made. Working in a male- or female-dominated professions for all categories of interruption except cateory four has the same positive or negative effect on wages. Working in a job in which more than 70 percent of all employees are women means an 8.8 to 10 percent lower hourly wage in comparison to a profession in which neither men nor women dominate. Conversely, a male-dominated job means a wage surplus of 8.8 to 11.1 percent, although the advantage of working in a male-dominated profession declines over time.

\section{Conclusions}

This paper analyzes the wage consequences of maternity leave, with a particular focus on a discrete separation of interruption types, a comparison of maternal and male wages in well-defined agegroups and the observation of wages over time.

Throughout our analysis, we confirm the results of Kuhlenkasper and Kauermann (2010), that the length of an interruption is determined by the education and human-resource wealth of mothers. The comparison of wages accruing to men and women within our subsamples and for the fragmented types of interruption expose a remarkable difference between mothers' labor market behavior when bearing children. When leaving the labor market, 
female employees already differ considerably from each other in terms of wages, education, actual working hours and type of profession. Women interrupting their careers for longer than one year are generally less educated, more likely to be employed in a female-dominated sector, are less likely to be given leadership tasks and less likely to be employed in the civil service. Note that in general, the civil service for women is associated with certain wage advantages.

Considering the absolute differences between mothers' and men's wages in their corresponding group, the wage penalty is larger, the longer the interruption period. This applies both in the short and long run. However, wage penalties for motherhood do not rise linearly with the length of an interruption. An initial differentiation can be made between mothers leaving employment for less than three years and those with longer interruptions. As expected, employment breaks of more than three years are associated with more extensive wage penalties than breaks of less than three years in the short run. Even though maternity leaves of more than three years are associated with wages that recover slightly in the long run, the difference compared to men's wages in the same agegroup remains remarkable with up to 25 percent. For shorter interruptions, no restoration of wages can be observed, but the male-female difference is not significant for mothers spending less than one year out of employment. Another surprising effect is the longterm situation for women leaving employment for up to three years. In this respect the wage difference is almost identical to the difference for women belonging to interruption type three.

Taking the initial levels of wages into account (when women leave employment), the results differ in the short, intermediate and long run. In the short run, when women reenter employment, theose who take break of up to three years 'only' forfeit some of their former wage advantage in comparison to men. In contrast, wage losses for women taking longer breaks are much larger and even rise until the third point of measurement five years after reentering employment. While, for the group of mothers in interruption type one, wages no longer differ significantly from their male counterparts in the long run, for group two, the wage deficit compared to men rises constantly. This finding supports our hypothesis of delayed wage penalties for maternity leave in this group. Altogether, in the long run, women interrupting their careers for one to three years are worst off. In this context women taking a short break of up to one year are the only ones having an advantage in terms of wage penalties. These results hold when controlling for years of missed 
experience; the coefficients are significant, but do not differ much between subgroups. While the results provide evidence of a delayed wage penalty, our hypothesis about increasing wage effects with an incerasing duration of maternity leave in the long run has to be rejected here, since the second group of mothers interrupting their careers face the highest relative wage penalty.

Alltogether, the separation of interruption types, rather than a linear observation of the length of maternity leaves, reveals a difference in wage penalties for women taking a break within job protected periods and beyond. Surprisingly, overall wage penalties are not smaller for women remaining within the protected period. While women taking a break longer than three years face an immidiate wage penalty which recovers (slightly) over time, the direct wage effect of shorter interruptions is smaller, but increases constantly over time. After ten years, mother-men wage gaps are the highest for women interrupting their careers for more than one, but less than three years. Furthermore, a development of female wages after interrupting their careers as Mincer and Ofek described, cannot be found for our dataset. Instead, maternity leave and the related wage penalty can only be compensated for over a lifetime and if the break is short enough. Every birth-related interruption longer than one year is associated with a wage penalty of at least twelve percent in comparison to male counterparts. This means that one child and a short maternity leave is the only possible way to combine family and career without severe wage losses. Our results demonstrate that reproductive behaviour in Germany already reflects the consequences. The legal protection of jobs and wages during maternity does not seem to have a long lasting effect on wage penalties for mothers leaving employment for more than one year. These results suggest the need for a policy that enhances mothers' career chances after interrupting their careers, given that demograpphic trends call for stronger incentives to have (larger) families in Germany. 


\section{References}

Anderson, Deborah J., Binder, Melissa, and Kate Krause. 2002. The Motherhood Wage Penalty: Which Mothers Pay it and Why? American Economic Review 92, no. 2: 354-358.

Anderson, Deborah J., Binder, Melissa, and Kate Krause. 2003. The Motherhood Wage Penalty Revisited: Experience, Heterogeneity, Work Effort, and Work-Schedule Flexibility. Industrial and Labor Relations Review 56, no.2: 273-294.

Anger, Silke, et al. 2011. Documentation PGEN. Person-related status and generated variables. Projektgruppe SOEP - DIW Berlin. http : //www.diw.de/documents/dokumentenarchiv/17/diw $1 . c .410636 . d e / p g e n-$ v28.pdf.

Beblo, Miriam, and Elke Wolf. 2003. Sind es die Erwerbsunterbrechungen? Ein Erklärungsbeitrag zum Lohnunterschied zwischen Frauen und Männern in Deutschland. Mitteilungen aus der Arbeitsmarkt- und Berufsforschung 36, no. 4: 560-572.

Becker, Gary S. 1964. Human Capital. Chicago: University Press.

Becker, Gary S. 1985. Human Capital, Effort and the Sexual Division of Labor. Journal of Labor Economics 3, no. 1: 33-58.

Budig, Michelle J., and Paula England. 2001. The Wage Penalty for Motherhood. American Sociological Review 66, no. 2: 204-225.

Busch, Anne, and Elke Holst. 2013. The Gender Pay Gap in Leadership and other White-Collar Positions in Germany: Putting the Relevance of Women's Share in Occupations into Context. Zeitschrift für Soziologie 42, no. 4: 315-336.

Ejrnoes, Mette, and Astrid Kunze. 2013. Work and Wage Dynamics around Childbirth. Scandinavian Journal of Economics 115, no. 3: 856-877.

Federal Statistical Office (edt.). 2013a. Statistik zum Elterngeld - Beendete Leistungsbezüge für im 1. Vierteljahr 2012 geborene Kinder - Januar 2012 bis Juni 2013. Federal Statistical Office. Wiesbaden.

Federal Statistical Office (edt.). 2013b. Regular Adaptation of the consumer Price Index (2013). Federal Statistical Office. Wiesbaden.

Goerlich, Dennis, and Andries de Grip. 2009. Human capital depretiation during hometime. Oxford Economic Papers, no. 61, i98-i121. 
Kuhlenkasper, Torben, and Göran Kauermann. 2009. Duration of maternity leave in Germany: A case study of nonparametric hazard models and penalized splines. Labour Economics 17, no. 3: 466-473.

Kunze, Astrid. 2002. The timing of careers and human capital depreciation. IZA Discussion Paper, no. 509..

Mincer, Jacob. 1974. Schooling, Experience and Earnings. New York: National Bureau of Economic Research.

Mincer, Jacob, and Haim Ofek. 1982. Interrupted Work Careers: Depreciation and Restoration of Human Capital. The Journal of Human Resources 17, no. 1: 3-24.

Mincer, Jacob, and Solomon Polachek. 1974. Family Investments in Human Capital: Earnings of Women. Journal of Political Economy 82, no. 2, pt. 2: 76-108

Oaxaca, Ronald. 1973. Male-female Wage Differentials in Urban Labor Markets. International Economic Review 14, no. 3: 693-709.

SOEP. 2011. Socio-Economic Panel Study, version 28, data for years 19842011. German Institute for Economic Research (DIW Berlin), Berlin: doi:10.5684/soep.v28.

Wagner, G. G., Frick, J. R., and Schupp, J. 2007. The German SocioEconomic Panel Study (SOEP) - scope, evolution and enhancemants. Schmollers Jahrbuch (Journal of Applied Social Science Studies) 127, no. 1: 139-169.

Waldfogel, Jane. 1997. The Effect of Children on Women's Wages. American Sociological Review 62, no. 2: 209-217.

Waldfogel, Jane. 1998. The Family Gap for Young Women in the United States and Britain: Can Maternity Leave Make a Difference? Journal of Labor Economics 16, no. 3: 505-545.

Ziefle, Andrea. 2004. Die individuellen Kosten des Erziehungsurlaubs: Eine empirische Analyse der kurz- und längerfristigen Folgen für den Karriereverlauf von Frauen. Kölner Zeitschrift für Soziologie und Sozialpsychologie 56, no. 2: 213-231. 


\section{Appendix}

\begin{tabular}{l|cccc}
\hline & Sample 1 & Sample 2 & Sample 3 & Sample 4 \\
& 0-1 years & 1-3 years & $3-6$ years & $6<$ years \\
\hline Withdrawal age & & & & \\
25th & 25 & 24 & 24 & 23 \\
50th & 27 & 27 & 27 & 26 \\
75th percentile & 30 & 30 & 31 & 29 \\
Number of Obs. & 168 & 278 & 171 & 315 \\
\hline Reentry age & & & & \\
25th & 27 & 28 & 29 & 32 \\
50 th & 30 & 30 & 32 & 35 \\
75 th percentile & 32 & 34 & 37 & 39 \\
Number of Obs. & 282 & 285 & 185 & 375 \\
\hline 5 years after reentry & & & & \\
25th & 31 & 32 & 33 & 36 \\
50th & 34 & 34 & 37 & 40 \\
75 th percentile & 36 & 37 & 40 & 43 \\
Number of Obs. & 192 & 205 & 137 & 306 \\
\hline 10 years after reentry & & & & \\
25th & 36 & 36 & 38 & 41 \\
50 th & 38 & 39 & 41 & 44 \\
75 th percentile & 41 & 41 & 44 & 48 \\
Number of Obs. & 137 & 126 & 91 & 186 \\
\hline
\end{tabular}

Table 4: Withdrawal and reentry ages by length of interruption period 


\begin{tabular}{|c|c|c|c|c|c|c|}
\hline $\begin{array}{l}\text { Category of } \\
\text { Interruption }\end{array}$ & $\begin{array}{l}\text { None } \\
\text { male }\end{array}$ & $\begin{array}{l}\text { None } \\
\text { female }\end{array}$ & $\begin{array}{c}\text { First } \\
0-1 \text { years }\end{array}$ & $\begin{array}{l}\text { Second } \\
1-3 \text { years }\end{array}$ & $\begin{array}{c}\text { Third } \\
\text { 3-6 years }\end{array}$ & $\begin{array}{l}\text { Fourth } \\
<6 \text { years }\end{array}$ \\
\hline Gross & 3284.39 & 1929.46 & 2065.56 & 1692.84 & 1522.47 & 1312.24 \\
\hline monthly wage & $(2518.80)$ & $(1439.57)$ & $(1301.99)$ & $(917.10)$ & $(949.67)$ & $(865.81)$ \\
\hline Gross & 18.63 & 14.20 & 15.31 & 13.38 & 12.48 & 11.62 \\
\hline hourly wage & $(12.47)$ & $(8.86)$ & $(8.27)$ & $(6.22)$ & $(6.33)$ & $(12.64)$ \\
\hline \multirow[t]{2}{*}{ Age } & 39.65 & 34.92 & 32.72 & 31.35 & 32.74 & 33.67 \\
\hline & $(12.09)$ & $(10.40)$ & $(8.37)$ & $(7.52)$ & $(8.33)$ & $(8.43)$ \\
\hline \multirow[t]{2}{*}{ Withdrawal age } & & 26.91 & 28.72 & 27.91 & 27.59 & 25.97 \\
\hline & & $(5.10)$ & $(4.60)$ & $(4.58)$ & $(5.03)$ & $(4.82)$ \\
\hline \multirow[t]{2}{*}{ Education (Years) } & 12.21 & 12.27 & 12.67 & 12.15 & 11.84 & 11.18 \\
\hline & $(2.71)$ & $(2.59)$ & $(2.66)$ & $(2.44)$ & $(2.46)$ & $(2.37)$ \\
\hline Actual working hours & 43.95 & 34.81 & 35.00 & 32.98 & 31.76 & 30.45 \\
\hline per week & $(9.53)$ & $(11.78)$ & $(11.71)$ & $(10.93)$ & $(12.43)$ & $(12.34)$ \\
\hline Full time & 18.06 & 7.87 & 7.27 & 6.24 & 6.06 & 4.44 \\
\hline experience & $(12.20)$ & $(8.13)$ & $(5.43)$ & $(4.74)$ & $(4.95)$ & $(4.65)$ \\
\hline Part time & 0.48 & 2.44 & 2.67 & 2.37 & 2.42 & 1.23 \\
\hline experience & $(1.66)$ & $(4.24)$ & $(4.02)$ & $(3.64)$ & $(3.55)$ & $(2.36)$ \\
\hline Share of part time & 0.07 & 0.26 & 0.240 & 0.24 & 0.27 & 0.25 \\
\hline experience & $(0.20)$ & $(0.33)$ & $(0.28)$ & $(0.28)$ & $(0.30)$ & $(0.34)$ \\
\hline Missed & 4.74 & 5.98 & 3.82 & 4.58 & 6.41 & 10.21 \\
\hline experience & $(4.08)$ & $(5.49)$ & $(3.13)$ & $(3.00)$ & $(3.85)$ & $(6.01)$ \\
\hline \multirow[t]{2}{*}{ married } & 0.25 & 0.17 & 0.43 & 0.46 & 0.50 & 0.65 \\
\hline & $(0.43)$ & $(0.38)$ & $(0.49)$ & $(0.49)$ & $(.50)$ & $(0.48)$ \\
\hline \multirow[t]{2}{*}{ Number of children } & 1.30 & 0.98 & 1.65 & 1.56 & 1.80 & 2.36 \\
\hline & $(1.20)$ & $(1.13)$ & $(0.70)$ & $(0.65)$ & $(0.78)$ & $(0.91)$ \\
\hline \multirow[t]{2}{*}{ Migration } & 0.12 & 0.16 & 0.13 & 0.13 & 0.19 & 0.27 \\
\hline & $(0.33)$ & $(0.36)$ & $(0.34)$ & $(0.34)$ & $(0.39)$ & $(0.44)$ \\
\hline \multirow[t]{2}{*}{ East Germany } & 0.1 & 0.07 & 0.12 & 0.15 & 0.09 & 0.07 \\
\hline & $(0.3)$ & $(0.26)$ & $(0.33)$ & $(0.36)$ & $(0.29)$ & $(0.24)$ \\
\hline Remaining household & 1312.08 & 2613.29 & 2424.65 & 2340.33 & 2412.02 & 2300.83 \\
\hline income & $(2666.64)$ & $(3651.21)$ & $(2936.44)$ & $(2226.49)$ & $(2532.86)$ & $(2213.33)$ \\
\hline \multirow[t]{2}{*}{ Leadership } & 0.16 & 0.08 & 0.11 & 0.07 & 0.04 & 0.07 \\
\hline & $(0.37)$ & $(0.26)$ & $(0.32)$ & $(0.26)$ & $(0.20)$ & $(0.13)$ \\
\hline \multirow[t]{2}{*}{ Civil Service } & 0.06 & 0.06 & 0.18 & 0.17 & 0.11 & 0.05 \\
\hline & $(0.24)$ & $(0.24)$ & $(0.39)$ & $(0.37)$ & $(0.32)$ & $(0.22)$ \\
\hline \multicolumn{7}{|l|}{ Company size (in \%) } \\
\hline 1-19 employees & 24.35 & 31.77 & 29.65 & 30.57 & 38.39 & 38.26 \\
\hline 20-199 employees & 28.05 & 27.59 & 26.65 & 24.49 & 22.35 & 27.48 \\
\hline 200-1999 employees & 22.12 & 20.16 & 19.67 & 22.36 & 18.53 & 19.23 \\
\hline 2000 or more employees & 25.48 & 20.47 & 24.03 & 22.57 & 20.74 & 15.03 \\
\hline \multicolumn{7}{|l|}{ Sector (in \%) } \\
\hline Industry & 37.55 & 16.89 & 16.98 & 19.99 & 16.46 & 21.66 \\
\hline Trade & 22.12 & 21.03 & 20.10 & 17.02 & 24.62 & 25.01 \\
\hline Service & 40.33 & 62.08 & 62.92 & 62.99 & 58.92 & 53.33 \\
\hline \multicolumn{7}{|l|}{ Profession (in \%) } \\
\hline dominated by women & 4.92 & 53.12 & 49.14 & 54.19 & 56.85 & 56.91 \\
\hline neutral & 23.58 & 36.33 & 38.85 & 36.49 & 33.38 & 34.30 \\
\hline dominated by men & 71.50 & 10.54 & 12.01 & 9.32 & 9.77 & 8.79 \\
\hline
\end{tabular}

Table 5: Descriptive statistics for males and females by category of interruption; standard deviations in parentheses 


\begin{tabular}{|c|c|c|c|c|}
\hline VARIABLES & $\begin{array}{c}(1) \\
\text { Withdrawal }\end{array}$ & $\begin{array}{c}(2) \\
\text { Reentry }\end{array}$ & $\begin{array}{c}(3) \\
5 \text { years } \\
\text { after reentry }\end{array}$ & $\begin{array}{c}(4) \\
10 \text { years } \_ \text {l_10 } \\
\text { after reentry }\end{array}$ \\
\hline Maternity Leave & $\begin{array}{c}0.111^{* * *} \\
(0.026)\end{array}$ & $\begin{array}{c}0.075^{* *} \\
(0.029)\end{array}$ & $\begin{array}{c}0.036 \\
(0.039)\end{array}$ & $\begin{array}{l}-0.053 \\
(0.039)\end{array}$ \\
\hline Years of education & $\begin{array}{c}0.011^{* * *} \\
(0.003)\end{array}$ & $\begin{array}{c}0.014^{* * *} \\
(0.003)\end{array}$ & $\begin{array}{c}0.030^{* * *} \\
(0.002)\end{array}$ & $\begin{array}{c}0.040^{* * * *} \\
(0.002)\end{array}$ \\
\hline Missed Experience & $\begin{array}{c}-0.017^{* * *} \\
(0.002)\end{array}$ & $\begin{array}{c}-0.015^{* * *} \\
(0.002)\end{array}$ & $\begin{array}{c}-0.017^{* * * *} \\
(0.002)\end{array}$ & $\begin{array}{c}-0.018^{* * *} \\
(0.002)\end{array}$ \\
\hline Marriage status & $\begin{array}{c}0.096^{* * *} \\
(0.009)\end{array}$ & $\begin{array}{c}0.087^{* * *} \\
(0.009)\end{array}$ & $\begin{array}{c}0.082 \text { *** } \\
(0.008)\end{array}$ & $\begin{array}{c}0.083^{* * *} \\
(0.008)\end{array}$ \\
\hline Migration background & $\begin{array}{c}-0.028^{* *} \\
(0.013)\end{array}$ & $\begin{array}{c}-0.033^{* *} \\
(0.013)\end{array}$ & $\begin{array}{c}-0.044^{* * *} \\
(0.011)\end{array}$ & $\begin{array}{c}-0.041^{* * *} \\
(0.010)\end{array}$ \\
\hline Res. in East Germany & $\begin{array}{c}-0.283^{* * *} \\
(0.011)\end{array}$ & $\begin{array}{c}-0.294^{* * *} \\
(0.010)\end{array}$ & $\begin{array}{c}-0.334^{* * *} \\
(0.009)\end{array}$ & $\begin{array}{c}-0.367^{* * *} \\
(0.009)\end{array}$ \\
\hline Rem. household income & $\begin{array}{c}-0.000^{* * *} \\
(0.000)\end{array}$ & $\begin{array}{c}-0.000^{* * *} \\
(0.000)\end{array}$ & $\begin{array}{c}-0.000^{* * *} \\
(0.000)\end{array}$ & $\begin{array}{c}-0.000^{* * *} \\
(0.000)\end{array}$ \\
\hline \multicolumn{5}{|l|}{ Company size $($ ref. $<20)$} \\
\hline $20-199$ & $\begin{array}{c}0.080^{* * *} \\
(0.013)\end{array}$ & $\begin{array}{c}0.081^{* * *} \\
(0.012)\end{array}$ & $\begin{array}{c}0.084^{* * *} \\
(0.010)\end{array}$ & $\begin{array}{c}0.080^{* * * *} \\
(0.010)\end{array}$ \\
\hline 200-1999 & $\begin{array}{c}0.198^{* * *} \\
(0.013)\end{array}$ & $\begin{array}{c}0.199^{* * *} \\
(0.012)\end{array}$ & $\begin{array}{c}0.179 * * * \\
(0.010)\end{array}$ & $\begin{array}{c}0.178^{* * *} \\
(0.010)\end{array}$ \\
\hline 2000 and more & $\begin{array}{c}0.233^{* * *} \\
(0.013)\end{array}$ & $\begin{array}{c}0.230^{* * *} \\
(0.012)\end{array}$ & $\begin{array}{c}0.220^{* * *} \\
(0.010)\end{array}$ & $\begin{array}{c}0.216^{* * *} \\
(0.010)\end{array}$ \\
\hline \multicolumn{5}{|l|}{ Sector (ref. Industry) } \\
\hline Trade & $\begin{array}{c}-0.062^{* * *} \\
(0.011)\end{array}$ & $\begin{array}{c}-0.060^{* * *} \\
(0.011)\end{array}$ & $\begin{array}{c}-0.094^{* * *} \\
(0.009)\end{array}$ & $\begin{array}{c}-0.082^{* * *} \\
(0.009)\end{array}$ \\
\hline Service & $\begin{array}{c}-0.059^{* * *} \\
(0.013)\end{array}$ & $\begin{array}{c}-0.038^{* * *} \\
(0.012)\end{array}$ & $\begin{array}{l}-0.012 \\
(0.009)\end{array}$ & $\begin{array}{c}0.007 \\
(0.009)\end{array}$ \\
\hline \multicolumn{5}{|c|}{ Profession (ref. intermediate) } \\
\hline Female & $\begin{array}{c}-0.088^{* * *} \\
(0.021)\end{array}$ & $\begin{array}{c}-0.093^{* * *} \\
(0.020)\end{array}$ & $\begin{array}{c}-0.085^{* * *} \\
(0.017)\end{array}$ & $\begin{array}{c}-0.051^{* * *} \\
(0.015)\end{array}$ \\
\hline Male & $\begin{array}{c}0.088^{* * *} \\
(0.012)\end{array}$ & $\begin{array}{c}0.076^{* * *} \\
(0.011)\end{array}$ & $\begin{array}{c}0.007 \\
(0.009)\end{array}$ & $\begin{array}{l}-0.010 \\
(0.008)\end{array}$ \\
\hline Leadership & $\begin{array}{c}0.218^{* * *} \\
(0.015)\end{array}$ & $\begin{array}{c}0.209^{* * *} \\
(0.014)\end{array}$ & $\begin{array}{c}0.197^{* * *} \\
(0.010)\end{array}$ & $\begin{array}{c}0.211^{* * *} \\
(0.009)\end{array}$ \\
\hline Civil Service & $\begin{array}{c}-0.072^{* * *} \\
(0.015)\end{array}$ & $\begin{array}{c}-0.077^{* * *} \\
(0.014)\end{array}$ & $\begin{array}{c}-0.069^{* * *} \\
(0.010)\end{array}$ & $\begin{array}{c}-0.080^{* * *} \\
(0.009)\end{array}$ \\
\hline Constant & $\begin{array}{c}2.381 * * * \\
(0.041)\end{array}$ & $\begin{array}{c}2.372^{* * *} \\
(0.039)\end{array}$ & $\begin{array}{c}2.372^{* * *} \\
(0.027)\end{array}$ & $\begin{array}{c}2.302^{* * *} \\
(0.025)\end{array}$ \\
\hline Observations & 8,966 & 9,522 & 11,895 & 13,288 \\
\hline R-squared & 0.231 & 0.248 & 0.340 & 0.387 \\
\hline
\end{tabular}

Table 6: Estimation results of the wage regression considering Sample one: men compared to mothers 


\begin{tabular}{|c|c|c|c|c|}
\hline VARIABLES & $\begin{array}{c}\text { (1) } \\
\text { Withdrawal }\end{array}$ & $\begin{array}{c}(2) \\
\text { Reentry }\end{array}$ & $\begin{array}{c}(3) \\
5 \text { years } \\
\text { after reentry }\end{array}$ & $\begin{array}{c}4) \\
10 \text { years } \\
\text { after reentry }\end{array}$ \\
\hline Maternity Leave & $\begin{array}{c}0.159^{* * *} \\
(0.030)\end{array}$ & $\begin{array}{c}0.010 \\
(0.043)\end{array}$ & $\begin{array}{l}-0.093^{*} \\
(0.050)\end{array}$ & $\begin{array}{l}-0.122^{*} \\
(0.063)\end{array}$ \\
\hline Years of education & $\begin{array}{l}0.007^{* *} \\
(0.003)\end{array}$ & $\begin{array}{c}0.018^{* * *} \\
(0.002)\end{array}$ & $\begin{array}{c}0.031 * * * \\
(0.002)\end{array}$ & $\begin{array}{c}0.042^{* * *} \\
(0.002)\end{array}$ \\
\hline Missed Experience & $\begin{array}{c}-0.021^{* * * *} \\
(0.002)\end{array}$ & $\begin{array}{c}-0.015^{* * *} \\
(0.002)\end{array}$ & $\begin{array}{c}-0.017^{* * *} \\
(0.002)\end{array}$ & $\begin{array}{c}-0.018^{* * *} \\
(0.002)\end{array}$ \\
\hline Marriage status & $\begin{array}{c}0.103^{* * *} \\
(0.010)\end{array}$ & $\begin{array}{c}0.081^{* * *} \\
(0.008)\end{array}$ & $\begin{array}{c}0.078^{* * *} \\
(0.008)\end{array}$ & $\begin{array}{c}0.080^{* * *} \\
(0.008)\end{array}$ \\
\hline Migration background & $\begin{array}{c}-0.028^{* *} \\
(0.014)\end{array}$ & $\begin{array}{c}-0.036^{* * *} \\
(0.013)\end{array}$ & $\begin{array}{c}-0.046^{* * *} \\
(0.012)\end{array}$ & $\begin{array}{c}-0.045^{* * *} \\
(0.011)\end{array}$ \\
\hline Res. in East Germany & $\begin{array}{c}-0.275^{* * *} \\
(0.012)\end{array}$ & $\begin{array}{c}-0.302^{* * * *} \\
(0.010)\end{array}$ & $\begin{array}{c}-0.336^{* * *} \\
(0.009)\end{array}$ & $\begin{array}{c}-0.371^{* * *} \\
(0.009)\end{array}$ \\
\hline Rem. household income & $\begin{array}{c}-0.000^{* * *} \\
(0.000)\end{array}$ & $\begin{array}{c}-0.000^{* * *} \\
(0.000)\end{array}$ & $\begin{array}{c}-0.000^{* * *} \\
(0.000)\end{array}$ & $\begin{array}{c}-0.000^{* * *} \\
(0.000)\end{array}$ \\
\hline \multicolumn{5}{|l|}{ Company size $($ ref. $<20)$} \\
\hline 20-199 & $\begin{array}{c}0.075^{* * *} \\
(0.013)\end{array}$ & $\begin{array}{c}0.081^{* * *} \\
(0.012)\end{array}$ & $\begin{array}{c}0.078^{* * *} \\
(0.011)\end{array}$ & $\begin{array}{c}0.075^{* * *} \\
(0.011)\end{array}$ \\
\hline 200-1999 & $\begin{array}{c}0.200^{* * *} \\
(0.015)\end{array}$ & $\begin{array}{c}0.197^{* * *} \\
(0.012)\end{array}$ & $\begin{array}{c}0.174^{* * *} \\
(0.011)\end{array}$ & $\begin{array}{c}0.178^{* * *} \\
(0.011)\end{array}$ \\
\hline 2000 and more & $\begin{array}{c}0.242^{* * *} \\
(0.014)\end{array}$ & $\begin{array}{c}0.234^{* * *} \\
(0.012)\end{array}$ & $\begin{array}{c}0.218^{* * *} \\
(0.011)\end{array}$ & $\begin{array}{c}0.212^{* * *} \\
(0.011)\end{array}$ \\
\hline \multicolumn{5}{|l|}{ Sector (ref. Industry) } \\
\hline Trade & $\begin{array}{c}-0.053^{* * *} \\
(0.012)\end{array}$ & $\begin{array}{c}-0.070^{* * *} \\
(0.010)\end{array}$ & $\begin{array}{c}-0.092^{* * *} \\
(0.010)\end{array}$ & $\begin{array}{c}-0.084^{* * *} \\
(0.010)\end{array}$ \\
\hline Service & $\begin{array}{c}-0.085^{* * *} \\
(0.015)\end{array}$ & $\begin{array}{c}-0.041^{* * *} \\
(0.011)\end{array}$ & $\begin{array}{l}-0.009 \\
(0.010)\end{array}$ & $\begin{array}{c}0.007 \\
(0.010)\end{array}$ \\
\hline \multicolumn{5}{|c|}{ Profession (ref. intermediate) } \\
\hline Female & $\begin{array}{c}-0.099^{* * *} \\
(0.023)\end{array}$ & $\begin{array}{c}-0.099 * * * \\
(0.020)\end{array}$ & $\begin{array}{c}-0.083^{* * *} \\
(0.018)\end{array}$ & $\begin{array}{c}-0.053^{* * *} \\
(0.016)\end{array}$ \\
\hline Male & $\begin{array}{c}0.105^{* * *} \\
(0.013)\end{array}$ & $\begin{array}{c}0.056^{* * *} \\
(0.011)\end{array}$ & $\begin{array}{c}0.002 \\
(0.009)\end{array}$ & $\begin{array}{l}-0.014 \\
(0.009)\end{array}$ \\
\hline Leadership & $\begin{array}{c}0.238^{* * *} \\
(0.017)\end{array}$ & $\begin{array}{c}0.198 * * * \\
(0.012)\end{array}$ & $\begin{array}{c}0.200^{* * *} \\
(0.011)\end{array}$ & $\begin{array}{c}0.212^{* * *} \\
(0.010)\end{array}$ \\
\hline Civil Service & $\begin{array}{c}-0.060^{* * *} \\
(0.016)\end{array}$ & $\begin{array}{c}-0.071^{* * *} \\
(0.013)\end{array}$ & $\begin{array}{c}-0.067^{* * *} \\
(0.011)\end{array}$ & $\begin{array}{c}-0.084^{* * *} \\
(0.010)\end{array}$ \\
\hline Constant & $\begin{array}{c}2.396^{* * *} \\
(0.045)\end{array}$ & $\begin{array}{c}2.375^{* * *} \\
(0.036)\end{array}$ & $\begin{array}{c}2.375^{* * * *} \\
(0.029)\end{array}$ & $\begin{array}{c}2.299^{* * *} \\
(0.027)\end{array}$ \\
\hline Observations & 8,133 & 10,026 & 10,289 & 11,494 \\
\hline R-squared & 0.229 & 0.264 & 0.359 & 0.390 \\
\hline
\end{tabular}

Table 7: Estimation results of the wage regression considering sample two: men compared to mothers 


\begin{tabular}{|c|c|c|c|c|}
\hline VARIABLES & $\begin{array}{c}(1) \\
\text { Withdrawal }\end{array}$ & $\begin{array}{c}(2) \\
\text { Reentry }\end{array}$ & $\begin{array}{c}(3) \\
5 \text { years } \\
\text { after reentry }\end{array}$ & $\begin{array}{c}4) \\
10 \text { years } \\
\text { after reentry }\end{array}$ \\
\hline Maternity Leave & $\begin{array}{c}0.080^{* *} \\
(0.040)\end{array}$ & $\begin{array}{c}-0.267^{* * *} \\
(0.063)\end{array}$ & $\begin{array}{c}-0.191 * * * \\
(0.056)\end{array}$ & $\begin{array}{c}-0.122^{* *} \\
(0.057)\end{array}$ \\
\hline Years of education & $\begin{array}{c}0.012^{* * *} \\
(0.003)\end{array}$ & $\begin{array}{c}0.027^{* * *} \\
(0.002)\end{array}$ & $\begin{array}{c}0.037^{* * *} \\
(0.002)\end{array}$ & $\begin{array}{c}0.045^{* * *} \\
(0.002)\end{array}$ \\
\hline Missed Experience & $\begin{array}{c}-0.020^{* * *} \\
(0.002)\end{array}$ & $\begin{array}{c}-0.015^{* * *} \\
(0.002)\end{array}$ & $\begin{array}{c}-0.018^{* * *} \\
(0.002)\end{array}$ & $\begin{array}{c}-0.017^{* * *} \\
(0.001)\end{array}$ \\
\hline Marriage status & $\begin{array}{c}0.129 * * * \\
(0.009)\end{array}$ & $\begin{array}{c}0.098^{* * *} \\
(0.007)\end{array}$ & $\begin{array}{c}0.076^{* * *} \\
(0.007)\end{array}$ & $\begin{array}{c}0.083^{* * *} \\
(0.008)\end{array}$ \\
\hline Migration background & $\begin{array}{c}-0.029^{* *} \\
(0.013)\end{array}$ & $\begin{array}{c}-0.046^{* * *} \\
(0.010)\end{array}$ & $\begin{array}{c}-0.040^{* * *} \\
(0.010)\end{array}$ & $\begin{array}{c}-0.045^{* * *} \\
(0.010)\end{array}$ \\
\hline Res. in East Germany & $\begin{array}{c}-0.282^{* * *} \\
(0.011)\end{array}$ & $\begin{array}{c}-0.322^{* * *} \\
(0.008)\end{array}$ & $\begin{array}{c}-0.356^{* * *} \\
(0.008)\end{array}$ & $\begin{array}{c}-0.390^{* * *} \\
(0.008)\end{array}$ \\
\hline Rem. household income & $\begin{array}{c}-0.000 * * * \\
(0.000)\end{array}$ & $\begin{array}{c}-0.000^{* * *} \\
(0.000)\end{array}$ & $\begin{array}{c}-0.000 * * * \\
(0.000)\end{array}$ & $\begin{array}{c}-0.000^{* * *} \\
(0.000)\end{array}$ \\
\hline \multicolumn{5}{|l|}{ Company size $($ ref. $<20)$} \\
\hline 20-199 & $\begin{array}{c}0.065^{* * *} \\
(0.012)\end{array}$ & $\begin{array}{c}0.082^{* * *} \\
(0.009)\end{array}$ & $\begin{array}{c}0.072^{* * *} \\
(0.009)\end{array}$ & $\begin{array}{c}0.062^{* * * *} \\
(0.010)\end{array}$ \\
\hline 200-1999 & $\begin{array}{c}0.189^{* * *} \\
(0.013)\end{array}$ & $\begin{array}{c}0.186^{* * *} \\
(0.009)\end{array}$ & $\begin{array}{c}0.169^{* * *} \\
(0.010)\end{array}$ & $\begin{array}{c}0.171^{* * *} \\
(0.010)\end{array}$ \\
\hline 2000 and more & $\begin{array}{c}0.231 * * * \\
(0.013)\end{array}$ & $\begin{array}{c}0.224^{* * *} \\
(0.009)\end{array}$ & $\begin{array}{c}0.215^{* * *} \\
(0.009)\end{array}$ & $\begin{array}{c}0.200^{* * *} \\
(0.010)\end{array}$ \\
\hline \multicolumn{5}{|l|}{ Sector (ref. Industry) } \\
\hline Trade & $\begin{array}{c}-0.058^{* * *} \\
(0.011)\end{array}$ & $\begin{array}{c}-0.081^{* * *} \\
(0.008)\end{array}$ & $\begin{array}{c}-0.090^{* * *} \\
(0.008)\end{array}$ & $\begin{array}{c}-0.072^{* * *} \\
(0.009)\end{array}$ \\
\hline Service & $\begin{array}{c}-0.090^{* * *} \\
(0.013)\end{array}$ & $\begin{array}{c}-0.018^{* *} \\
(0.008)\end{array}$ & $\begin{array}{l}-0.005 \\
(0.008)\end{array}$ & $\begin{array}{c}0.007 \\
(0.009)\end{array}$ \\
\hline \multicolumn{5}{|c|}{ Profession (ref. intermediate) } \\
\hline Female & $\begin{array}{c}-0.087 * * * \\
(0.022)\end{array}$ & $\begin{array}{c}-0.084^{* * *} \\
(0.016)\end{array}$ & $\begin{array}{c}-0.062^{* * *} \\
(0.014)\end{array}$ & $\begin{array}{c}-0.042^{* * *} \\
(0.015)\end{array}$ \\
\hline Male & $\begin{array}{c}0.098^{* * *} \\
(0.012)\end{array}$ & $\begin{array}{c}0.029 * * * \\
(0.008)\end{array}$ & $\begin{array}{l}-0.004 \\
(0.008)\end{array}$ & $\begin{array}{l}-0.014^{*} \\
(0.008)\end{array}$ \\
\hline Leadership & $\begin{array}{c}0.253^{* * *} \\
(0.015)\end{array}$ & $\begin{array}{c}0.198^{* * *} \\
(0.009)\end{array}$ & $\begin{array}{c}0.207^{* * *} \\
(0.009)\end{array}$ & $\begin{array}{c}0.221^{* * *} \\
(0.009)\end{array}$ \\
\hline Civil Service & $\begin{array}{c}-0.057 * * * \\
(0.015)\end{array}$ & $\begin{array}{c}-0.076^{* * *} \\
(0.010)\end{array}$ & $\begin{array}{c}-0.071^{* * *} \\
(0.009)\end{array}$ & $\begin{array}{c}-0.080^{* * *} \\
(0.009)\end{array}$ \\
\hline Constant & $\begin{array}{c}2.337^{* * *} \\
(0.040)\end{array}$ & $\begin{array}{c}2.3355^{* * *} \\
(0.026)\end{array}$ & $\begin{array}{c}2.332^{* * *} \\
(0.024)\end{array}$ & $\begin{array}{c}2.283^{* * *} \\
(0.025)\end{array}$ \\
\hline Observations & 10,352 & 15,901 & 14,542 & 15,650 \\
\hline R-squared & 0.236 & 0.315 & 0.380 & 0.385 \\
\hline
\end{tabular}

Table 8: Estimation results of the wage regression considering Sample three: men compared to mothers 


\begin{tabular}{|c|c|c|c|c|}
\hline VARIABLES & $\begin{array}{c}\text { (1) } \\
\text { Withdrawal }\end{array}$ & $\begin{array}{c}(2) \\
\text { Reentry }\end{array}$ & $\begin{array}{c}(3) \\
5 \text { years } \\
\text { after reentry }\end{array}$ & $\begin{array}{c}4) \\
10 \text { years } \\
\text { after reentry }\end{array}$ \\
\hline Maternity Leave & $\begin{array}{c}0.030 \\
(0.044)\end{array}$ & $\begin{array}{c}-0.189^{* *} \\
(0.076)\end{array}$ & $\begin{array}{c}-0.251^{* * *} \\
(0.056)\end{array}$ & $\begin{array}{c}-0.234^{* * *} \\
(0.077)\end{array}$ \\
\hline Years of education & $\begin{array}{c}0.004 \\
(0.004)\end{array}$ & $\begin{array}{c}0.033^{* * *} \\
(0.002)\end{array}$ & $\begin{array}{c}0.043^{* * *} \\
(0.002)\end{array}$ & $\begin{array}{c}0.049^{* * *} \\
(0.002)\end{array}$ \\
\hline Missed Experience & $\begin{array}{c}-0.025^{* * *} \\
(0.003)\end{array}$ & $\begin{array}{c}-0.018^{* * *} \\
(0.002)\end{array}$ & $\begin{array}{c}-0.018^{* * *} \\
(0.001)\end{array}$ & $\begin{array}{c}-0.012^{* * *} \\
(0.001)\end{array}$ \\
\hline Marriage status & $\begin{array}{c}0.121^{* * *} \\
(0.011)\end{array}$ & $\begin{array}{c}0.089 * * * \\
(0.007)\end{array}$ & $\begin{array}{c}0.083^{* * *} \\
(0.007)\end{array}$ & $\begin{array}{c}0.092^{* * *} \\
(0.008)\end{array}$ \\
\hline Migration background & $\begin{array}{l}-0.020 \\
(0.016)\end{array}$ & $\begin{array}{c}-0.041^{* * *} \\
(0.010)\end{array}$ & $\begin{array}{c}-0.045^{* * *} \\
(0.010)\end{array}$ & $\begin{array}{c}-0.071^{* * *} \\
(0.011)\end{array}$ \\
\hline Res. in East Germany & $\begin{array}{c}-0.269^{* * *} \\
(0.014)\end{array}$ & $\begin{array}{c}-0.347^{* * *} \\
(0.008)\end{array}$ & $\begin{array}{c}-0.381 * * * \\
(0.008)\end{array}$ & $\begin{array}{c}-0.409^{* * *} \\
(0.008)\end{array}$ \\
\hline Rem. household income & $\begin{array}{c}-0.000^{* * *} \\
(0.000)\end{array}$ & $\begin{array}{c}-0.000^{* * *} \\
(0.000)\end{array}$ & $\begin{array}{c}-0.000^{* * *} \\
(0.000)\end{array}$ & $\begin{array}{c}-0.000^{* *} \\
(0.000)\end{array}$ \\
\hline \multicolumn{5}{|l|}{ Company size $($ ref. $<20)$} \\
\hline 20-199 & $\begin{array}{c}0.068^{* * *} \\
(0.015)\end{array}$ & $\begin{array}{c}0.075 * * * \\
(0.009)\end{array}$ & $\begin{array}{c}0.072 * * * \\
(0.010)\end{array}$ & $\begin{array}{c}0.061^{* * *} \\
(0.011)\end{array}$ \\
\hline 200-1999 & $\begin{array}{c}0.187^{* * *} \\
(0.017)\end{array}$ & $\begin{array}{c}0.172 * * * \\
(0.009)\end{array}$ & $\begin{array}{c}0.180^{* * *} \\
(0.010)\end{array}$ & $\begin{array}{c}0.175^{* * * *} \\
(0.011)\end{array}$ \\
\hline 2000 and more & $\begin{array}{c}0.237^{* * *} \\
(0.016)\end{array}$ & $\begin{array}{c}0.212^{* * *} \\
(0.009)\end{array}$ & $\begin{array}{c}0.209^{* * *} \\
(0.010)\end{array}$ & $\begin{array}{c}0.210^{* * *} \\
(0.011)\end{array}$ \\
\hline \multicolumn{5}{|l|}{ Sector (ref. Industry) } \\
\hline Trade & $\begin{array}{c}-0.047^{* * *} \\
(0.013)\end{array}$ & $\begin{array}{c}-0.094^{* * *} \\
(0.008)\end{array}$ & $\begin{array}{c}-0.074^{* * *} \\
(0.009)\end{array}$ & $\begin{array}{c}-0.064^{* * *} \\
(0.009)\end{array}$ \\
\hline Service & $\begin{array}{c}-0.107^{* * *} \\
(0.017)\end{array}$ & $\begin{array}{l}-0.012 \\
(0.008)\end{array}$ & $\begin{array}{c}0.003 \\
(0.009)\end{array}$ & $\begin{array}{l}-0.002 \\
(0.009)\end{array}$ \\
\hline \multicolumn{5}{|c|}{ Profession (ref. intermediate) } \\
\hline Female & $\begin{array}{c}-0.090^{* * *} \\
(0.026)\end{array}$ & $\begin{array}{c}-0.065^{* * *} \\
(0.015)\end{array}$ & $\begin{array}{c}-0.048^{* * *} \\
(0.015)\end{array}$ & $\begin{array}{c}-0.056^{* * *} \\
(0.018)\end{array}$ \\
\hline Male & $\begin{array}{c}0.111^{* * *} \\
(0.014)\end{array}$ & $\begin{array}{c}0.002 \\
(0.008)\end{array}$ & $\begin{array}{c}-0.016^{* *} \\
(0.008)\end{array}$ & $\begin{array}{c}-0.027^{* * *} \\
(0.008)\end{array}$ \\
\hline Leadership & $\begin{array}{c}0.258^{* * *} \\
(0.020)\end{array}$ & $\begin{array}{c}0.207^{* * *} \\
(0.009)\end{array}$ & $\begin{array}{c}0.219^{* * *} \\
(0.009)\end{array}$ & $\begin{array}{c}0.225^{* * *} \\
(0.009)\end{array}$ \\
\hline Civil Service & $\begin{array}{c}-0.057^{* * *} \\
(0.019)\end{array}$ & $\begin{array}{c}-0.071^{* * *} \\
(0.009)\end{array}$ & $\begin{array}{c}-0.077^{* * *} \\
(0.009)\end{array}$ & $\begin{array}{c}-0.063^{* * *} \\
(0.009)\end{array}$ \\
\hline Constant & $\begin{array}{c}2.402^{* * *} \\
(0.052)\end{array}$ & $\begin{array}{c}2.354^{* * *} \\
(0.024)\end{array}$ & $\begin{array}{c}2.288^{* * *} \\
(0.025)\end{array}$ & $\begin{array}{c}2.238^{* * *} \\
(0.026)\end{array}$ \\
\hline Observations & 7,393 & 15,625 & 15,480 & 15,539 \\
\hline R-squared & 0.210 & 0.355 & 0.381 & 0.393 \\
\hline
\end{tabular}

Table 9: Estimation results of the wage regression considering sample four: men compared to mothers 


\begin{tabular}{|c|c|c|c|c|}
\hline VARIABLES & $\begin{array}{c}(1) \\
\text { Withdrawal }\end{array}$ & $\begin{array}{c}(2) \\
\text { Reentry }\end{array}$ & $\begin{array}{c}(3) \\
5 \text { years } \\
\text { after reentry }\end{array}$ & $\begin{array}{c}(4) \\
10 \text { years _l_10 } \\
\text { after reentry }\end{array}$ \\
\hline Woman & $\begin{array}{c}-0.025^{*} \\
(0.013)\end{array}$ & $\begin{array}{c}-0.078^{* * *} \\
(0.010)\end{array}$ & $\begin{array}{c}-0.129^{* * *} \\
(0.010)\end{array}$ & $\begin{array}{c}-0.142^{* * *} \\
(0.011)\end{array}$ \\
\hline Years of education & $\begin{array}{c}0.008^{* * *} \\
(0.003)\end{array}$ & $\begin{array}{c}0.023^{* * *} \\
(0.002)\end{array}$ & $\begin{array}{c}0.036^{* * *} \\
(0.002)\end{array}$ & $\begin{array}{c}0.043^{* * *} \\
(0.002)\end{array}$ \\
\hline Missed Experience & $\begin{array}{c}-0.025^{* * *} \\
(0.002)\end{array}$ & $\begin{array}{c}-0.018^{* * *} \\
(0.002)\end{array}$ & $\begin{array}{c}-0.021^{* * * *} \\
(0.001)\end{array}$ & $\begin{array}{c}-0.020 * * * \\
(0.001)\end{array}$ \\
\hline Marriage status & $\begin{array}{c}0.132^{* * *} \\
(0.009)\end{array}$ & $\begin{array}{c}0.085^{* * *} \\
(0.007)\end{array}$ & $\begin{array}{c}0.068 * * * \\
(0.007)\end{array}$ & $\begin{array}{c}0.062^{* * *} \\
(0.007)\end{array}$ \\
\hline Migration background & $\begin{array}{c}-0.039^{* * *} \\
(0.014)\end{array}$ & $\begin{array}{c}-0.044^{* * * *} \\
(0.011)\end{array}$ & $\begin{array}{c}-0.046^{* * *} \\
(0.010)\end{array}$ & $\begin{array}{c}-0.050 * * * \\
(0.010)\end{array}$ \\
\hline Res. in East Germany & $\begin{array}{c}-0.278^{* * *} \\
(0.011)\end{array}$ & $\begin{array}{c}-0.317^{* * * *} \\
(0.008)\end{array}$ & $\begin{array}{c}-0.360 * * * \\
(0.008)\end{array}$ & $\begin{array}{c}-0.391^{* * *} \\
(0.009)\end{array}$ \\
\hline Rem. household income & $\begin{array}{c}-0.000^{* * *} \\
(0.000)\end{array}$ & $\begin{array}{c}-0.000 * * * \\
(0.000)\end{array}$ & $\begin{array}{c}-0.000^{* *} \\
(0.000)\end{array}$ & $\begin{array}{l}-0.000 \\
(0.000)\end{array}$ \\
\hline \multicolumn{5}{|l|}{ Company size $($ ref. $<20$ ) } \\
\hline 20-199 & $\begin{array}{c}0.052^{* * *} \\
(0.012)\end{array}$ & $\begin{array}{c}0.082^{* * *} \\
(0.009)\end{array}$ & $\begin{array}{c}0.077^{* * *} \\
(0.009)\end{array}$ & $\begin{array}{c}0.071^{* * *} \\
(0.010)\end{array}$ \\
\hline 200-1999 & $\begin{array}{c}0.155^{* * *} \\
(0.013)\end{array}$ & $\begin{array}{c}0.176^{* * *} \\
(0.009)\end{array}$ & $\begin{array}{c}0.163^{* * *} \\
(0.009)\end{array}$ & $\begin{array}{c}0.168^{* * * *} \\
(0.010)\end{array}$ \\
\hline 2000 and more & $\begin{array}{c}0.191^{* * *} \\
(0.012)\end{array}$ & $\begin{array}{c}0.220^{* * *} \\
(0.010)\end{array}$ & $\begin{array}{c}0.213^{* * *} \\
(0.009)\end{array}$ & $\begin{array}{c}0.203^{* * *} \\
(0.011)\end{array}$ \\
\hline \multicolumn{5}{|l|}{ Sector (ref. Industry) } \\
\hline Trade & $\begin{array}{c}-0.087^{* * *} \\
(0.011)\end{array}$ & $\begin{array}{c}-0.091^{* * * *} \\
(0.009)\end{array}$ & $\begin{array}{c}-0.105^{* * *} \\
(0.008)\end{array}$ & $\begin{array}{c}-0.088^{* * *} \\
(0.009)\end{array}$ \\
\hline Service & $\begin{array}{c}-0.089^{* * *} \\
(0.012)\end{array}$ & $\begin{array}{c}-0.031^{* * *} \\
(0.009)\end{array}$ & $\begin{array}{l}-0.014^{*} \\
(0.008)\end{array}$ & $\begin{array}{l}-0.006 \\
(0.009)\end{array}$ \\
\hline \multicolumn{5}{|c|}{ Profession (ref. intermediate) } \\
\hline Female & $\begin{array}{l}-0.019 \\
(0.014)\end{array}$ & $\begin{array}{c}-0.066^{* * *} \\
(0.012)\end{array}$ & $\begin{array}{c}-0.077^{* * * *} \\
(0.011)\end{array}$ & $\begin{array}{c}-0.053^{* * *} \\
(0.013)\end{array}$ \\
\hline Male & $\begin{array}{c}0.107 * * * \\
(0.012)\end{array}$ & $\begin{array}{c}0.034^{* * *} \\
(0.008)\end{array}$ & $\begin{array}{c}-0.018^{* *} \\
(0.008)\end{array}$ & $\begin{array}{c}-0.020^{* *} \\
(0.008)\end{array}$ \\
\hline Leadership & $\begin{array}{c}0.260^{* * *} \\
(0.014)\end{array}$ & $\begin{array}{c}0.197^{* * *} \\
(0.009)\end{array}$ & $\begin{array}{c}0.201^{* * *} \\
(0.009)\end{array}$ & $\begin{array}{c}0.212^{* * *} \\
(0.009)\end{array}$ \\
\hline Civil Service & $\begin{array}{l}-0.022 \\
(0.013)\end{array}$ & $\begin{array}{c}-0.043^{* * *} \\
(0.010)\end{array}$ & $\begin{array}{c}-0.056^{* * *} \\
(0.008)\end{array}$ & $\begin{array}{c}-0.061^{* * *} \\
(0.009)\end{array}$ \\
\hline Constant & $\begin{array}{c}2.413^{* * * *} \\
(0.038)\end{array}$ & $\begin{array}{c}2.398^{* * *} \\
(0.027)\end{array}$ & $\begin{array}{c}2.395^{* * *} \\
(0.023)\end{array}$ & $\begin{array}{c}2.343^{* * *} \\
(0.025)\end{array}$ \\
\hline Observations & 12,099 & 15,168 & 17,038 & 15,737 \\
\hline R-squared & 0.212 & 0.289 & 0.358 & 0.362 \\
\hline
\end{tabular}

Table 10: Estimation results of the wage regression: men compared to women without children 